\title{
Do Not Process
}

National Cancer Institute

\section{Source}

National Cancer Institute. Do Not Process. NCI Thesaurus. Code C154309.

An indication that a biospecimen should not be subjected to any treatment. 